РОЗВИТОК ПІЗНАВАЛЬНОЇ САМОСТІЙНОСТІ НА УРОКАХ МАТЕМАТИКИ В ПОЧАТКОВІЙ ШКОЛІ

\title{
THE DEVELOPMENT OF COGNITIVE SELF-DIRECTION IN ELEMENTARY SCHOOL STUDENTS IN MATHEMATICS LESSONS
}

Трансформації в сучасній педагогічній освіті демонструють необхідність у вирішенні актуальної проблеми - розвитку пізнавальної самостійності молодших школярів. Пізнавальна самостійність - це складне комплексне поняття в освітньому процесі початкової школи. Здебільшого вчителі дотримувалися такої думки, що досить сорормувати у дітей навички логічного мислення відповідно до їхніх вікових особливостей за допомогою підібраних методів. Однак результати досліджень дедалі більше переконували педагогів у неповноті й однобічності такого трактування.

Важливою $є$ роль уроків математики у вирішенні цієї проблеми, адже саме вони допомагають розширювати кругозір учнів, розвивати самостійність поглядів, формувати критичність, алгоритмічність мислення, спрямовувати учнів на здійснення пошукової діяльності, активізують пізнавальну діяльність.

у роботі розкрито визначення основних дефрініцій дослідження: самостійність, пізнавальна самостійність. Проаналізовано теоретичні та методичні аспекти розвитку пізнавальної самостійності на уроках математики у початковій школі. Розкрито основні умови та шляхи розвитку досліджуваного френомену. Сконцентровано увагу на різних видах завдань, які сприяють активізації мислення молодших школярів, розвивають їхню самостійність і прагнення до пізнання навколишнього світу.

Наведено приклади проектів, уроків-казок, які рекомендуються для активного застосування у початковій школі на уроках математики. Проаналізовані прийоми інтерактивного навчання, які під час активізації пізнавальної діяльності набувають великого значення: «Акваріум», «Коло ідей», «Мозковий штурм», «Мікрофон», «Навчаючись учусь», «Займи позицію» та багато інших. Визначені умови, які впливають на розвиток пізнавальної самостійності молодших школярів на уроках математики та прагнення виконати завдання математичного характеру якнайкраще.

Ключові слова: самостійність, пізнавальна самостійність, розвиток пізнавальної самостійності, уроки математики, молодший шкільний вік, дидактичні ігри, творчі задачі, проекти.

Transformations at modern pedagogical education demonstrate the need to solve an urgent problem - the development of cognitive self-direction of primary school students. Cognitive independence is a complex complex concept in the educational process of primary school. Usually teachers were of the opinion that it is enough to form in children the skills of logical thinking in accordance with their age with the help of selected methods. However, the results of the study increasingly convinced teachers of the incompleteness and one-sidedness of this interpretation.

The role of mathematics lessons is very important, because it help to broaden the horizons of primary school childrans, develop self-confidence of views, form of critical thinking, algorithmic thinking, direct pupils to search activities, enhance cognitive activity etc. The paper reveals the definition of the main definitions of the study, namely: self-direction, cognitive selfdirection.

The article analyzed theoretical and methodological aspects of the development of cognitive self-direction in mathematics lessons in primary school. The main conditions and ways of development of the studied phenomenon are revealed. The focus is on different types of tasks that enhance the thinking of younger students, develop their independence and desire to learn about the world around them.

Examples of projects, lessons-fairy tales are recommendedfor active application atelementary school in lessons of mathematics. The methods of interactive learning are analyzed, which become very important during the activation of cognitive activity. Namely: "Aquarium", "Circle of ideas", "Brainstorming", "Microphone", "Learning - learning", "Take a position" and many others. The conditions that affect the development of cognitive independence of primary school students in mathematics lessons and the desire to perform mathematical tasks as best as possible are identified.

Key words: self-direction, cognitive selfdirection, development of cognitive self-direction, mathematics lessons, primary school age, didactic games, creative tasks, projects.
Постановка проблеми в загальному вигляді. Науково-технічний прогрес, зміна самосвідомості суспільства вимагають від освітньої сфери відповідних реакцій, спрямованих на підвищення рівня освіти, визначення правильних орієнтирів і тенденцій щодо розвитку нового покоління.

Враховуючи досвід зарубіжних країн та аналізуючи стан сучасної освіти, варто звернути увагу на розвиток пізнавальної самостійності учнів, починаючи 3 перших класів. Саме 3 початкової ланки відбувається формування зрілої самостій- ності. Розвивати в учнів уміння критично мислити, аналізувати та прагнути до самовдосконалення, пізнання нових явищ і процесів - досить складне і кропітке завдання. Вирішувати цю проблему варто системно, розкриваючи шляхи підвищення ефективності уроків математики.

Аналіз останніх досліджень і публікацій. Серед сучасних вчених, які займаються вивченням різних аспектів пізнавальної самостійності, найбільш відомими є Ю. Демидова (займається визначенням першооснов пізнавальної самостій- 
ності у конструктивній діяльності), Г. Ковтонюк (досліджує психолого-педагогічні засади організації самостійної пізнавальної діяльності школярів), Г. Люблінська (зосереджує свою увагу на різних видах самостійних завдань як основній умові розвитку пізнавальної самостійності), Л. Лутченко (вивчає організацію самостійної навчально-пізнавальної діяльності учнів у процесі вивчення математики), І. Трубавіна (акцентує увагу на важливому значенні випереджаючих пізнавальних завдань як засобі організації самостійної роботи молодших школярів), О. Савченко (досліджує основи розвитку пізнавальної самостійності молодших школярів), В. Тюріна (розглядає шляхи фоормування пізнавальної самостійності учнів), Є. Улятовська (вивчає особливості підготовки майбутніх вчителів до роботи з активізації самостійної пізнавальної діяльності молодших школярів), І. Хом'юк (розглядає самостійну роботу та шляхи розвитку пізнавальної самостійності молодших школярів).

Виділення не вирішених раніше частин загальної проблеми. Вивченням проблеми розвитку пізнавальної самостійності займаються здебільшого у середніх і старших класах. Початкова ланка школи не досить досліджує це питання. Аналіз наукових праць дає підстави стверджувати, що ця тема не досить відображена у джерелознавчій базі. Саме тому ми дослідили вказане питання та визначили шляхи його вирішення.

Мета статті. Основною метою статті $€$ визначення головних умов та шляхів розвитку пізнавальної самостійності молодших школярів на уроках математики.

Виклад основного матеріалу. Для розуміння сутності досліджуваного питання визначимо його категорійний апарат. У психологічному словнику самостійність визначається як узагальнена властивість особистості, яка виявляється в ініціативності, критичності, адекватній самооцінці й почутті особистої відповідальності за свою діяльність і поведінку. Така її властивість пов'язана з активною роботою думки, почуттів і волі. Розвиток розумових і емоційно-вольових процесів $є$ необхідною передумовою для самостійних суджень і дій, судження і дії, які складаються у процесі самостійної діяльності, зміцнюють і формують здатність не тільки виконувати свідомо мотивовані дії, але й домагатися успішного виконання прийнятих рішень всупереч можливим труднощам [9, с. 449].

Під поняттям «самостійність» ми розуміємо свідоме мотивування дій та їх обґрунтованість, не піддавання чужим впливам, прагнення і здатність чинити згідно зі своїми особистими переконаннями. Усвідомлене бажання дітей до здійснення самостійної діяльності розпочинається 3 молодшого шкільного віку, коли дитина вже починає пізнавати навчальний матеріал і розуміти дійсність 3 більш наукової точки зору.
Розглядаючи десрініцію «пізнавальна самостійність», відомий дидакт М. Данилов зазначав, що її суть виявляється у потребі й умінні учнів самостійно мислити, у здатності орієнтуватися в новій ситуації, знаходити відповіді на поставлені питання та визначати шляхи їх розв'язку. Прикладом пізнавальної самостійності $€$ вміння учнів самостійно аналізувати складні навчальні задачі і виконувати їх без сторонньої допомоги. У такий спосіб школяр виявляє критичне мислення, демонструє здатність висловлювати свою точку зору [3]. Науковець Г. Люблінська під цим поняттям розглядає здатність учня не тільки розуміти матеріал, але й застосовувати його в нових видах самостійних завдань.

Згідно із наведеними визначеннями пізнавальна самостійність молодшого школяра фрормується не як результат дій одного ефективного засобу, а $є$ закономірним продуктом досконалої системи навчання й виховання учнів на уроці, спрямованої на всебічний розвиток самостійності мислення і самостійності як риси характеру дитини.

Для розвитку досліджуваного френомену освітній процес у початковій школі має спрямовуватися на формування у школярів пізнавальних потреб; розвиток наполегливості у виконанні самостійних завдань; раціональне поєднання репродуктивної і продуктивної діяльності школярів (доцільно збільшувати кількість частково-пошукових методів); запровадження у зміст навчання спеціальної системи пізнавальних завдань, яка оптимально забезпечує пізнавальну, розвиваючу і виховну фрункції навчання; використання ефективних засобів керування пошуковою діяльністю молодших школярів через поступове ускладнення і варіювання змістом пізнавальних завдань; удосконалення інтелектуальних вмінь, загальних і спеціальних прийомів навчальної роботи молодших школярів; активне застосування проектної діяльності; застосування нестандартних уроків-казок, спрямованих на активізацію пізнавальної самостійності учнів; підтримку та налагодження позитивної пошукової атмоссрери у класі; створення ситуацій успіху для кожного школяра. Зазначені умови не є вичерпними, однак, на нашу думку, вони є основними для застосування у практичній діяльності.

Науковці Н. Родюк, В. Хом'юк, І. Хом'юк наголошують на важливості використання комплексних задач, побудованих на основі наочного обладнання або запису на дошці. Завдання у таких задачах мають бути лаконічними та чіткими. Також вчені рекомендують використовувати інсрормаційні (наприклад, знайди та запиши ті приклади, відповіді на які дорівнюють 9, 17, 20, 31, 29-3; 31+9; $18-9 ; 40-25 ; 17-9 ; 16+4 ; 42+6 ; 35-4 ; 25-0 ; 12+5)$ та дослідницькі (доведи, що якщо число ділиться і на 2, і на 3, то воно ділиться і на їх добуток) завдання. 
Ще одним типом завдань, визначених вченими, є завдання на аналогію, порівняння, структурування навчального матеріалу. На думку науковців саме завдяки таким видам завдань у молодших школярів формується пізнавальна самостійність, підсилюється бажання пізнавати та вивчати явища, які їх оточують [8].

Окрім зазначених варіантів завдань, варто використовувати різні методи і прийоми навчання: творчі вправи, проблемні задачі і запитання, евристичні бесіди, дидактичні ігри, проекти, задачі 3 казковим чи гумористичним сюжетом. Прикладами завдань із казковими образами, казковими сюжетами є:

Задача 1. Маса булави Котигорошка дорівнює 60 кг, а маса його шаблі у 12 разів менша. Яка загальна маса булави та шаблі Котигорошка?

Задача 2. Колобок біг від бабусі та дідуся і зустрів по дорозі вовка. Утікач пообіцяв вовку заспівати пісеньку 5 разів, а заспівав лише двічі. На скільки менше заспівав пісеньку Колобок вовку, ніж обіцяв? Скільки разів Колобок заспівав бабусі та дідусю?

У початковій школі необхідно впроваджувати дидактичні ігри. Прикладами таких ігор на уроках математики $€$ «Хто швидше?», «Магазин», «Мовчанка», «Кругові приклади», «Відгадай задумане число», «Що потім?», «Геометрична мозаїка», «Домалюй фрігуру», «Закінчи приклад», «Де моє місце?», «Мій бюджет на місяць», «У магазині іграшок» [4]. Такі завдання розвивають творчість, критичне мислення, оптимізують пошукову діяльність учнів, вчать їх розуміти, що задача / приклад / проблема / питання можуть мати кілька шляхів вирішення й потрібно знаходити той, який є найоптимальнішим для конкретного учня. Вони мотивують учнів до самовдосконалення та сприяють активізації пізнавальної самостійності.

Під час активізації пізнавальної діяльності велике значення має використання прийомів інтерактивного навчання: «Акваріум», «Коло ідей», «Мозковий штурм», «Мікрофон», «Навчаючись - учусь», «Займи позицію». На уроках педагог має постійно здійснювати інтелектуальноемоційну підтримку учнів на основі авансування. Це передбачає підхід до дитини 3 оптимістичною гіпотезою, вірою в ії здібності й успіхи, що в подальшому впливає на розвиток пізнавальної самостійності школярів [7].

Нині актуальною є проектна діяльність. Саме завдяки створенню проектів учні розвивають пізнавальну самостійність. На наш погляд, цьому методу варто приділяти більше уваги на уроках математики. На допомогу вчителю прийдуть збірники проектів, розроблених В. Алєксєєвим і В. Даніліною. У їхніх працях розміщені варіанти проектів для різних класів. Ці напрацювання допоможуть ефрективно здійснювати проектну діяльність на уроках математики в початковій школі [1; 2].

Темами проектів можуть бути пошуководослідницькі проекти «Математика на кухні», «Найвідоміші математики планети», «Математика в казках», складання таблиці витрат матеріалів «Ремонт у моїй оселі»; творчі проекти «Числова мозаїка», ілюстрування задач «Математична газета», «Намалюймо задачу». Можна залучати учнів до постановки ігрових вистав «Як виникла математика?», «Як зайчик моркву рахував?» [6].

Для успішного використання запропонованих методів, прийомів, завдань, спрямованих на розвиток пізнавальної самостійності молодших школярів на уроках математики, потрібно враховувати такі умови: розвиток пізнавальної самостійності має проводитися планомірно і систематично; під час вибору методів, прийомів, завдань, при визначенні їх обсягу та змісту необхідно керуватися принципами доступності, поступовості у наростанні труднощів, диференційованим підходом до учнів; вчитель має так сорормулювати завдання, щоб викликати у школярів інтерес до роботи і прагнення виконати їі якнайкраще.

Висновки. Для успішного розвитку пізнавальної самостійності у молодших школярів необхідно фрормувати пізнавальні проблеми, розвивати бажання й уміння працювати самостійно, наполегливо досягати результатів у виконанні поставлених перед ними завдань. Шляхами такого розвитку $є$ раціональне поєднання репродуктивної і продуктивної діяльності з метою доцільного збільшення питомої ваги частково-пошукових методів: запровадження у зміст початкового навчання спеціальної системи пізнавальних завдань, використання ефективних засобів керування пошуковою діяльністю молодших школярів на різних етапах навчання, розв'язування завдань, які вимагають від учнів логічного розмірковування, комбінування, аналізу та синтезу.

Оскільки ця проблема не є вичерпною, подальшими перспективними дослідженнями є вивчення впливу інфрормаційних засобів навчання на розвиток пізнавальної самостійності молодших школярів.

\section{БІБЛІОГРАФІЧНИЙ СПИСОК:}

1. Алєксєєв В.Є. Проекти. Початкова школа. К. : Перше вересня, 2018. 112 с.

2. Даніліна І.В. Проектна діяльність 4 клас. Навчальні проекти в початковій школі: докладні розробки уроків-презентацій проектів, шаблони для копіювання. К. : Основа, 2016. 168 с.

3. Данилов М.О. Виховання у школярів самостійності та творчої активності в процесі навчання. М., 1981. C. 33.

4. Ковтонюк Г.М. Психолого-педагогічні засади організації самостійної пізнавальної діяльності школярів : посіб. Вінниця : Едельвейс і К, 2012. 143 с. 
5. Микичур Т.С. Проблема гуманно-ціннісного виховання дітей у педагогічній спадщині В.О. Сухомлинського. Реалізація ідей В.О. Сухомлинського в практиці роботи сучасної початкової школи : збірник матеріалів регіональних педагогічних читань. Вінниця : ВДПУ ім. М. Коцюбинського, 2012. Вип. 8. С. 128-129.

6. Онопрієнко О. Вивчення математичних понять і закономірностей у проектній діяльності. Вчитель початкової школи. 2017. № 2. С. 7-9.
7. Савченко О.Я. Розвиток пізнавальної самостійності молодших школярів. К. : Радянська школа, 1982. $175 \mathrm{c}$.

8. Хом'юк І.В. Шляхи формування пізнавальної самостійності молодших школярів на уроках математики. К. : Молодий вчений, 2019. № 5.2 (69.2). C. $166-169$.

9. Шапар В.Б. Психологічний тлумачний словник. X. : Прапор, 2004. 640 c. 